\title{
GAMMARUS ORINOS N. SP. FROM THE MASSIF CENTRAL (FRANCE): ITS GENETIC AND MORPHOLOGICAL DISTINCTION FROM GAMMARUS IBERICUS MARGALEF, 1951 (CRUSTACEA, AMPHIPODA)
}

\author{
by \\ SJOUK PINKSTER \\ Institute of Taxonomic Zoology, University of Amsterdam, P.O. Box 20125, \\ 1000 HC Amsterdam, The Netherlands
}

\&

ADOLF SCHOLL

Institute of Zoology, University of Berne, Baltzerstr. 3, CH-3012, Berne, Switzerland

\begin{abstract}
SUMMARY
Until 1974 Gammarus ibericus was known only from the type-locality in Spain. In that year, Goedmakers recorded the species from many localities in the Massif Central, France. Indeed, these populations show a great morphological resemblance to the Spanish ones. These French populations were used in cross-breeding experiments with other populations from southern France, without result. Attempts to hybridize these populations with the $G$. ibericus from the type-locality also failed to produce any offspring. Electrophoretic studies showed that the French and Spanish populations are very different from a biochemical point of view; these differences are much greater than between any of the known freshwater species (or populations) from western Europe. It is therefore decided that the populations from the Massif Central belong to a separate species: $G$. orinos $n$. sp. Careful examination of hundreds of specimens from both Spain and France showed that minor but constant morphological differences exist between the two species.
\end{abstract}

\section{RÉSUMÉ}

Jusqu'en 1974 Gammarus ibericus était uniquement connu de la localité-type d'Espagne. C'est en 1974 que Goedmakers mentionna l'espèce de nombreuses localités du Massif Central (France), en se fondant sur des populations qui montrent réellement une forte ressemblance morphologique avec celles d'Espagne. Les populations du Massif Central ont été utilisées pour des expériences de croisement avec des populations de France méridionale, mais sans résultat positif. De même, des essais d'hybridation de populations de $G$. ibericus de la localité-type n'ont pas donné de progéniture. Des recherches électrophorétiques ont montré que les populations de France et
d'Espagne sont nettement différentes du point de vue biochimique, ces différences étant beaucoup plus importantes que celles séparant n'importe quelles autres espèces (ou populations) d'Europe occidentale. On est donc arrivé à la conclusion que les populations du Massif Central appartiennent à une espèce distincte, $G$. orinos n. sp. L'examination minutieuse de centaines d'exemplaires d'Espagne et de France a montré que des différences morphologiques mineures mais constantes existent entre les deux espèces.

\section{INTRODUCTION}

1. In 1951 Margalef described Gammarus ibericus from the Fuentes de la Laguna "El Tobar" in the Serrania de Cuenca, central Spain. In spite of intensive search throughout the Iberian peninsula (e.g. Pinkster, 1971, 1973) the species was never found outside a very restricted area near the type-locality. Goedmakers (1974) who systematically sampled the entire Massif Central in the middle of France, came upon populations that resembled $G$. ibericus in almost every morphological character and she decided that they were conspecific.

Pinkster (1983) studied many morphologically different populations from southern France and in hybridization experiments tested the significance of the morphological differences observed. Since some of the populations used (population C) showed a close resemblance to 
the so-called ibericus from the Massif Central, a population of these was also used in the experiments. However, no offspring could ever be obtained from these experiments. Other populations from southern France proved to be interfertile and were described as $G$. stupendus by Pinkster, 1983. In the light of the previous experiments, the question arose if these populations from the Massif Central are conspecific with $G$. ibericus indeed. A new series of hybridization experiments was started with $G$. ibericus from the type-locality and a population from central France.

2. Bulnheim \& Scholl $(1980,1981)$ demonstrated that electrophoretic criteria can be additionally used as diagnostic aids in the taxonomy of gammarids. The criteria are related to relative electrophoretic mobilities of the protein products from selected loci and the distribution of allele frequencies at polymorphic loci.

The present authors discussed each other's methods and agreed to start a preliminary program to investigate taxonomic problems in freshwater gammarids by applying the different methods described (electrophoresis, hybridization experiments, morphological studies) to the same populations. So, all populations used by Pinkster (1983) in his hybridization experiments have been electrophoretically analyzed, together with a new series of populations, including $G$. ibericus from Spain and central France. New series of hybridization experiments were run simultaneously.

Although the experiments are still going on, and the results obtained so far do not yet allow a more comprehensive discussion of all taxa investigated, they definitely shed new light on the position of $G$. ibericus from Spain and the populations from the Massif Central.

\section{EXPERIMENTAL PART}

\section{Hybridization experiments}

Methods. - The methods used were identical to those described by Pinkster (1983); after a period of adaptation all experiments were run at $15^{\circ} \mathrm{C}$. In February 1983 a series of experiments was started with freshly collected animals from the Laguna "El Tobar", prov. Cuenca, Spain, and with a population from a small brook near Ste. Marguérite, dépt. Ardèche, France.

Results. - The results can be easily summarized as follows: cross-breeding was attempted between more than a hundred mature males of both populations and the same number of females from the other populations. In six months hardly any precopulations were found and oviposition took place in less than $10 \%$ of the females. Offspring were never observed. The homogeneous crosses from both populations did very well in the experiments, easily formed precopulations and had a high percentage of success $(60 \%)$.

\section{Electrophoretic studies}

Methods. - The methods of electrophoretic separation of enzymes and specific staining techniques are those of Bulnheim \& Scholl (1981). The following enzymes were assayed: arginine phosphokinase (APK), glutamate oxalacetate (two genetically independent enzymes GOT-1 and GOT-2), hexokinase (HK), leucine aminopeptidase (LAP), mannose-6-phosphate isomerase (MPI), and phosphoglucose isomerase (PGI). In addition, indophenol oxidase (IPO) was scored (an achromatic region which appeared upon prolonged staining on HK- and MPI-zymograms).

Fourteen individuals from each of the two populations (El Tobar and Ste. Marguérite) were analyzed.

Results. - The two populations differed electrophoretically in seven out of eight enzymes analyzed. Electrophoretic identity was only observed for leucine aminopeptidase. Fig. 1 shows a representative zymogram of one of the electrophoretically different enzymes, phosphoglucose isomerase.

To evaluate the significance of these observations with respect to the systematics of the gam- 
marids concerned, reference must be made to previous investigations of Bulnheim \& Scholl (1981), using essentially the same methods and enzyme samples in comparison of ten European gammarid species from marine, brackish and freshwater habitats. The subspecies $G$. duebeni duebeni and $G$. duebeni celticus could not be distinguished electrophoretically. Genetic differentiation of the sibling species $G$. zaddachi and $G$. salinus was observed on the basis of allele frequencies at polymorphic enzyme loci.

Thus, the electrophoretic studies reported here indicate a very high degree of genetic differentiation of the two populations compared, which is far beyond the level expected in allopatric populations of a single species.

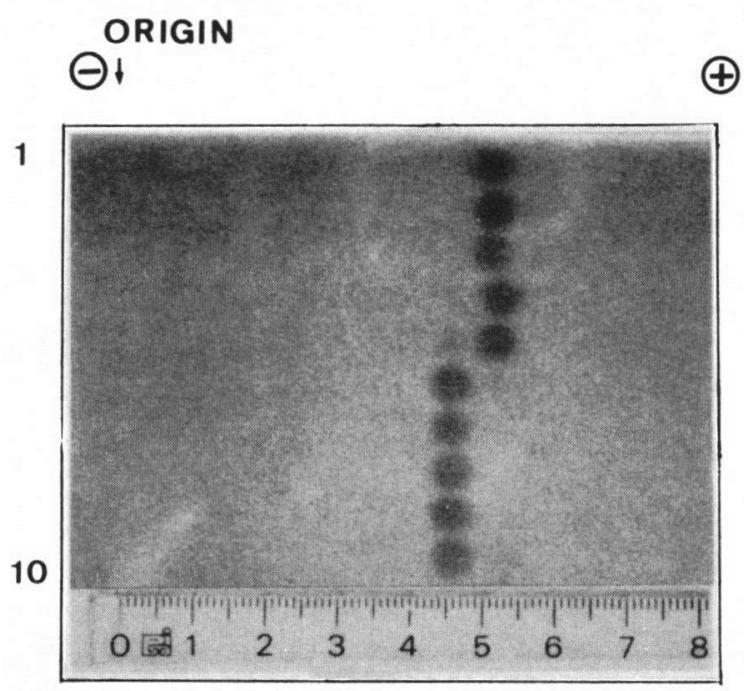

Fig. 1. Zymogram of phosphoglucose isomerase. Slots 1 to 5 contained the extracts of 5 specimens of $G$. orinos $n$. sp., slots 6 to 10 contained the extracts of 5 specimens of $G$. ibericus.

\section{CONCLUSIONS}

Considering the results of both the crossbreeding and the biochemical experiments, as well as those of earlier experiments (Pinkster, 1983; Bulnheim \& Scholl, 1980, 1981), we must conclude that the populations from Spain and the Massif Central are not conspecific and that consequently the French populations belong to a hitherto undescribed species which mor- phologically highly resembles $G$. ibericus while being genetically well differentiated. Careful morphological examination of this species (which is called Gammarus orinos, because of its distribution pattern in the old mountainous Massif Central) and G. ibericus reveals some small but constant differences (see the sequel).

\section{DESCRIPTIVE PART}

\section{Gammarus orinos n. sp.}

Material examined. - Thirty-five samples, all from the Massif Central, France (for details see appendix). A distribution map is published by Pinkster, 1983, fig. 6 (as G. ibericus, non Margalef). Locus typicus: France, dépt. Ardèche, small brook $6 \mathrm{~km}$ E. of Chirols (near Vals-lesBains), 17-VII-1981; many specimens, many in precopulation. The male holotype and 60 paratypes have been deposited in the collections of the Zoölogisch Museum, Amsterdam, coll. no. ZMA Amph. 107.744 a-b; 10 paratypes have been deposited in the Naturhistorisches Museum Bern (NMBE), Switzerland.

Diagnosis. - Small to medium-sized species with a smooth, slender body. Moderately setose second antenna. Pereiopods 5 to 7 always armed with long setae in between the spines. The dorsal surface of the urosome is flat.

Description.- Male: maximum length observed $14 \mathrm{~mm}$. The urosome segments have no dorsal excavations or elevations. The dorsal armature consists of a mid-dorsal group of spines and setae and a lateral group on each side on all three urosome segments (fig. 3I). The eyes are small, of the $G$. pulex-type.

The first antenna is poorly setose, without special characteristics. Peduncle segments 4 and 5 of the second antenna (fig. 2A) are armed with 5 to 7 groups of setae along the lower margin, which are usually longer than the diameter of the segments on which they are implanted. Calceoli are always present.

The mouthparts are of the usual $G$. pulex-type (see Karaman \& Pinkster, 1977); so a regular comb-like row of equally long setae is found along the lower margin of the third segment of the mandibular palp. 


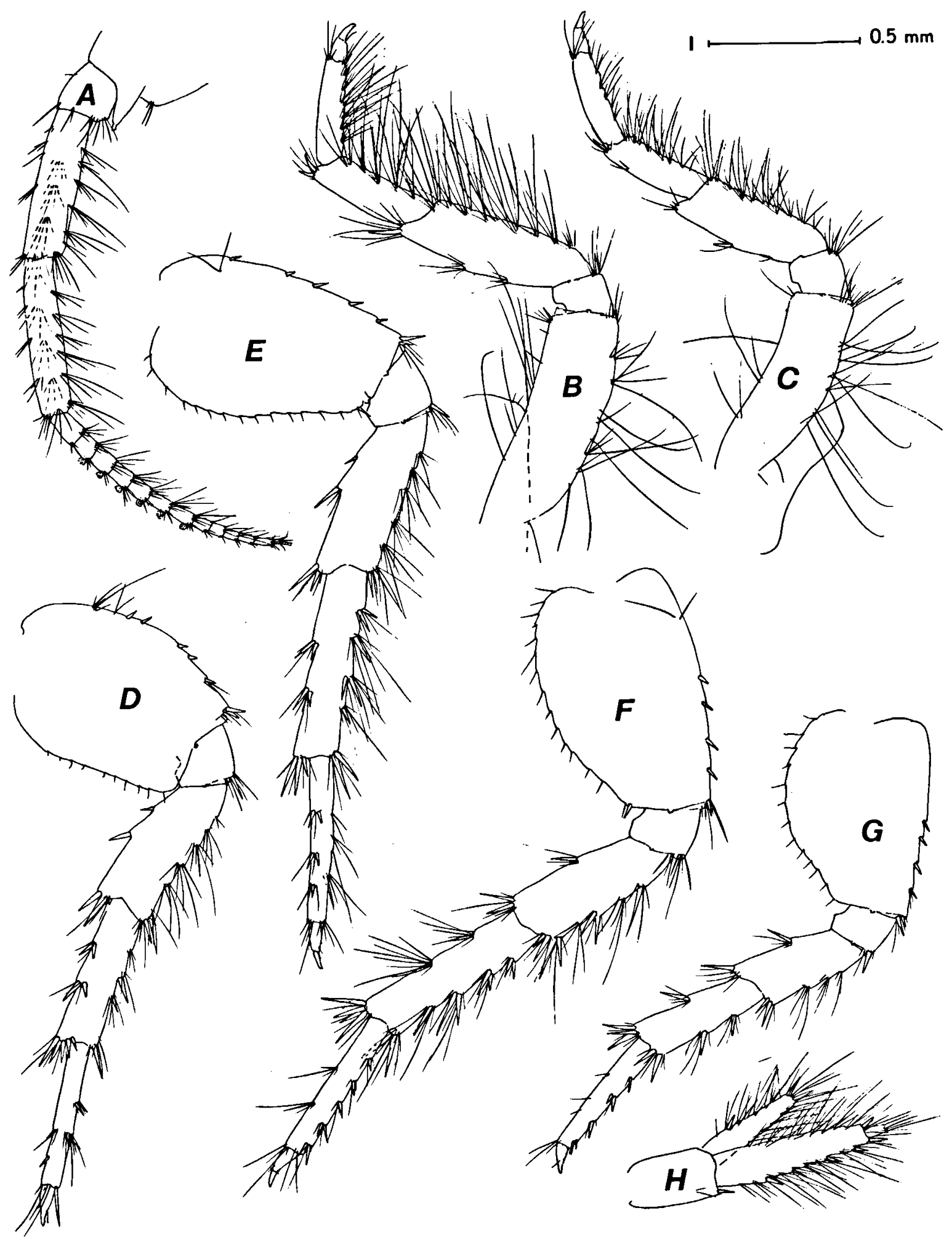

Fig. 2. Gammarus orinos n. sp., A-F and H, o from the type-locality: A, second antenna; B, third pereiopod; C, fourth pereiopod; D, fifth pereiopod; E, sixth pereiopod; F, seventh pereiopod; H, third uropod; G, $\odot$ from the type-locality, seventh pereiopod (all scale I). 


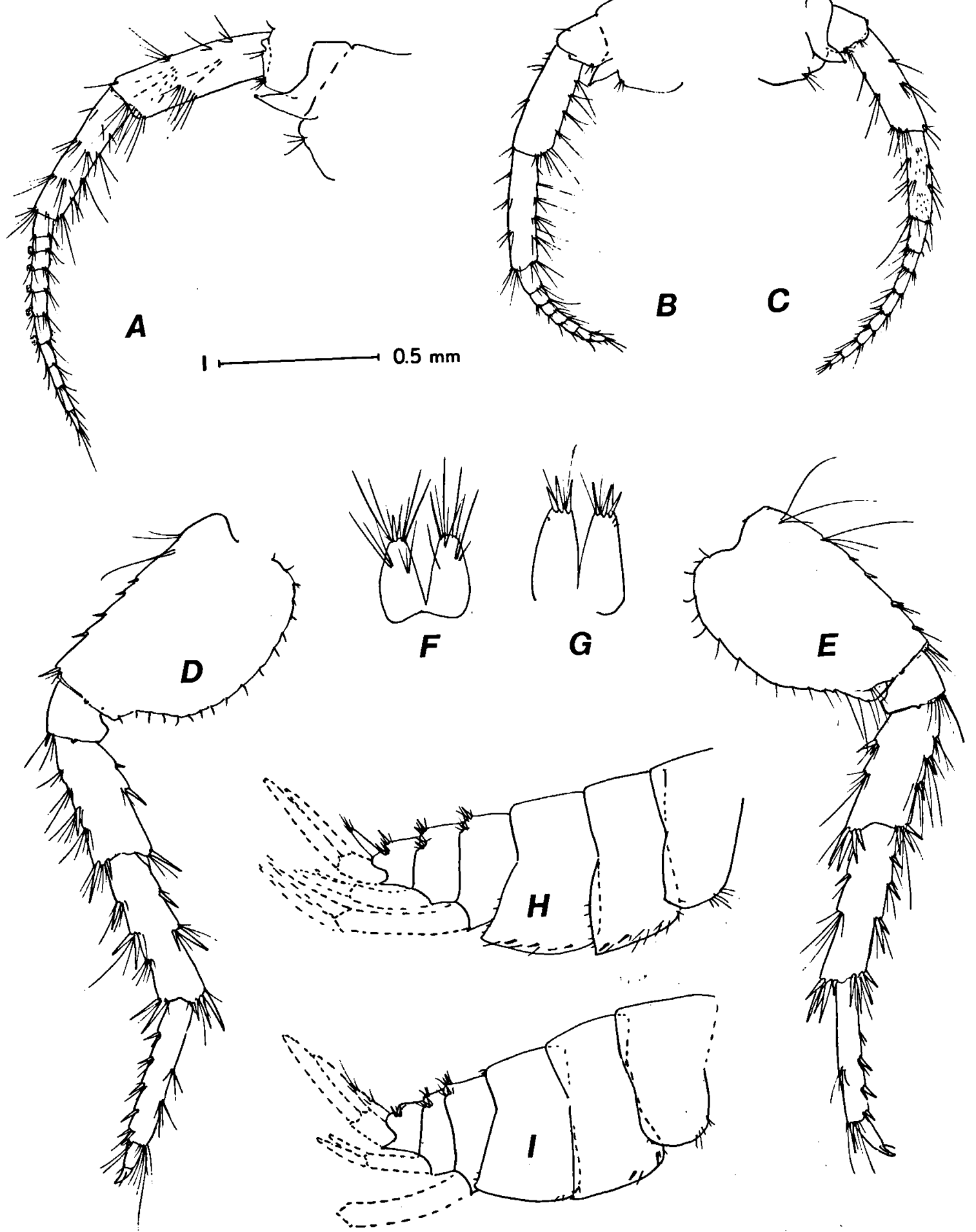

Fig. 3. A, C, E, G and H, Gammarus ibericus Margalef, 1951, from the type-locality: A, second antenna of $\sigma^{\circ}$; C, second antenna of $\odot ; E$, seventh pereiopod of $\odot ; G$, telson lobes (both sexes); H, meta- and urosome of $\sigma^{\circ}$.

B, D, F, and I, Gammarus orinos n. sp. from the type-locality: B, second antenna of $\$ ; D$, seventh pereiopod of $\$ ; \mathrm{F}$, telson lobes (both sexes); I, meta- and urosome of $\sigma^{\circ}$ (all scale I). 
The first and second gnathopods, including the propodi, resemble those of $G$. ibericus in shape and armature. The setation is relatively long. Pereiopods 3 and 4 (figs. 2B, C) are not very characteristic. In $\mathrm{P} 4$ the setation is rather short.

Pereiopods 5 to 7 have relatively short basal segments (figs. 2D, E, F), never being more than 1.5 times as long as wide in P7. The armature of the other segments consists of a number of strong spines and many long setae which are usually longer than the spines. The number and length of these setae increases with age.

The epimeral plates (fig. 3I) are rounded (in the 1 st) to rectangular or slightly pointed (in the 3rd).

The endopodite of uropod 3 is about $2 / 3$ of the length of the exopodite (fig. $2 \mathrm{H}$ ). The setae along the outer margin of the exopodite are always simple and can be very long.

The telson lobes (fig. 3F) are twice as long as wide. Apart from the terminal group of spines and setae, several other groups of long setae can be found on the dorsal surface of the lobes.

Female: Sexual dimorphism can be observed in the size and shape of the second antenna (fig. 3B), the size and shape of the gnathopods and the size of the pereiopods. In P7 the basal segment is constricted near its distal end (fig. 2G).

Variability. - The variability pattern of this species is of the same type as that described for G. p. pulex (see Karaman \& Pinkster, 1977). Apart from this, variability is also observed in the length of the setae on the pereiopods. In summer they are generally longer than during the winter months; moreover, the length of these setae increases with age.

Remarks and affinities.- So far this species has been identified as $G$. ibericus Margalef, 1951 (Goedmakers, 1974; Pinkster, 1983). Careful examination of many samples and hundreds of (adult) specimens of the new species and $G$. ibericus from two localities in Spain revealed that some constant morphological differences exist: (1) Peduncle seg- ment 4 of A2 (in both sexes) bears 5 to 7 groups of setae in $G$. orinos versus 1 to 4 in $G$. ibericus. (2) The telson lobes of $G$. orinos are always armed with groups of setae on the dorsal surface, which never occur in $G$. ibericus. (3) The basal segment of $\mathrm{P} 7$ in female $G$. ibericus is always set with some long setae near its distal end, these are never present in G. orinos (compare figs. 3D and E). (4) The epimeral plates of $G$. ibericus are more setose than in $G$. orinos (compare figs. $3 \mathrm{H}$ and I ). (5) In male G. ibericus the outer margin of uropod 3 is set with plumose setae, a character never found in $G$. orinos.

$G$. orinos also resembles some populations of G. stupendus (forma C), but it differs from it in the presence of calceoli in A2 and the longer endopodite of uropod 3. More evidence is provided by cross-breeding experiments (Pinkster, 1983).

Like $G$. ibericus, this new species has setiferous pereiopods 5 to 7 , a character that can also be found in $G$. acalceolatus Pinkster, 1971, G. rambouseki (S. Karaman, 1931), G. syriacus Chevreux, 1895, $G$. agrarius (G. Karaman, 1973) and G. rouxi Pinkster \& Goedmakers, 1975. However, all these species always differ in many other characteristics from the newly described species (see Karaman \& Pinkster, 1977).

\section{ACKNOWLEDGEMENTS}

We are indebted to Mrs. M. Goris for her help in collecting the material in France and Spain and to Mr. B. van den Hoek for his help in running the cross-breeding experiments; to Mrs. V. Siegfried and Mrs. L. Frauchiger for their careful technical assistance in the electrophoretic studies.

\section{REFERENCES}

Bulnheim, H. P. A. Scholl, 1980. Evidence of genetic divergence between two brackish-water gammaridean sibling species. Mar. Ecol. Progr. Ser., 3: 163-165.

- - - 1981. Electrophoretic approach to the biochemical systematics of gammarids. Helgoländer Meeresunters., 34: 391-400.

Goedmakers, A., 1974. Les Gammaridae (Crustacés, Amphipodes) du Massif Central. Bull. zool. Mus. Univ. Amsterdam, 3 (23): 211-219. 
Karaman, G. S. \& S. Pinkster, 1977. Freshwater Gammarus species from Europe, North Africa and adjacent regions of Asia (Crustacea-Amphipoda). Part I. Gammarus pulex-group and related species. Bijdr. Dierk., 47 (1): 1-97.

Margalef, R., 1951. Sobre Gammarus interesantes de España. Publnes. Inst. Biol. apl. Barcelona, 9: 255269.

Pinkster, S., 1971. Members of the Gammarus pulex- group (Crustacea-Amphipoda) from North Africa and Spain, with description of a new species from Morocco. Bull. zool. Mus. Univ. Amsterdam, 2 (7): 45-61.

- 1973. The Echinogammarus berilloni-group, a number of predominantly Iberian amphipod species (Crustacea). Bijdr. Dierk., 43 (1): 1-38, map III.

- , 1983. The value of morphological characters in the taxonomy of Gammarus. Beaufortia, 33 (2): 15-28.

Received: 14 February 1984 


\section{APPENDIX}

Localities of Gammarus orinos n. sp. in central and southern France.

Dépt. Ardeche:

- Aubenas, Vals-les-Bains, 6 km E. of Chirols, 1 km E. of Oubreyts, 17-VII-1981, ZMA Amph. 107.744, (a) 10 holotype, (b) 70 paratypes.

- Aubenas, 3 km E. of Chirols, 17-VII-1981, ZMA Amph. 107.745, many specimens.

- Aubenas, $3 \mathrm{~km}$ E. of Chirols, D 253 near crossroad to Romegières, 17-VII-1981, ZMA Amph. 107.746, many specimens.

- Aubenas, 5 km E. of Chirols, Vals-les-Bains, 21-V-1972, ZMA Amph. 103.793a, many specimens.

- Aubenas, river Bourges, $2.5 \mathrm{~km}$ S.E. of Burzet, 5-IV-1972, ZMA Amph. 103.793b, 1 specimen.

Dépt. Cantal:

- Aurillac, affluent of river Cère near La Mon. Neuve, VI-1971, ZMA Amph. 103.043, 10 specimens.

- L'Auze, $70 \mathrm{~km} \mathrm{E}$. of Tulle, $4 \mathrm{~km} \mathrm{~S}$. of Mauriac, 21-VI-1972, ZMA Amph. 103.811, many specimens.

- Le Rioux Tort, $30 \mathrm{~km} \mathrm{E.} \mathrm{of} \mathrm{Argentat,} 3 \mathrm{~km} \mathrm{~W}$. of Pléaux, 21-VI-1972, ZMA Amph. 103.811, many specimens.

- Affluent of river Cère, $20 \mathrm{~km} \mathrm{~W}$. of Aurillac, E. of Montvert, 22-VI-1972, ZMA Amph. 103.811, many specimens.

- Affluent of river Célé, $40 \mathrm{~km}$ S.S.W. of Aurillac, 5 km E. of Maurs, 18-VII-1972, ZMA Amph. 103.811, many specimens.

- L'Auze near Junhac, $30 \mathrm{~km}$ S. of Aurillac, 18-VII-1972, ZMA Amph. 103.811, many specimens.

Dépt. Corrèze:

- $5 \mathrm{~km}$ E. of Argentat, E. of Brive, 21-VI-1972, ZMA Amph. 103.804, many specimens.

- Affluent of river Maronne, $7 \mathrm{~km}$ S.E. of Argentat near la Broquerie, 22-VI-1972, ZMA Amph. 103.804, many specimens.

\section{Dépt. Dordogne:}

- Rivulet Fosso near Les Eyzies, 27-VII-1972, ZMA Amph. 106.006, 3 specimens.

- Rivulet Nauze near Siorac-en-Perigord, VI-1971,
ZMA Amph. 103.010, 6 specimens.

- Urval, near St. Cyprien, VI-1971, ZMA Amph. 103.011, many specimens.

- Rivulet Beuze, Lazarc near St. Cyprien, VI-1971, ZMA Amph. 103.012, many specimens.

- Rivulet Vallée, Grives near St. Cyprien, VI-1971, ZMA Amph. 103.013, many specimens.

- Rivulet Lémance near Besse, VI-1971, ZMA Amph. 103.014, many specimens.

- Rivulet Beuze, Doissat near St. Cyprien, VI-1971, ZMA Amph. 103.015, many specimens.

- Rivulet Enea, Carcac near Sarlat-la-Canéda, VI-1971, ZMA Amph. 103.016, many specimens.

Dépt. Gard:

- Bagnols-sur-Cèze, $1 \mathrm{~km}$ S.E. of Montelus, 18-VII-1981, ZMA Amph. 107.747, many specimens.

- Alès, 2 km W. of St. Hippolyte, 4-IV-1972, ZMA Amph. 103.819, 2 specimens.

- Alès, rivulet Crespenou, $6 \mathrm{~km} \mathrm{E}$. of St. Hippolyte, 4-IV-1972, ZMA Amph. 103.819, many specimens.

Dépt. Hérault:

- Montpellier, rivulet Alzon, near St. Bauzille-dePutois, 1-IV-1972, ZMA Amph. 103.728, many specimens.

- Montpellier, river Hérault near Valrac, 1-IV-1972, ZMA Amph. 103.728, many specimens.

- Montpellier, river Hérault near Pont-St.-Etienne, 23-V-1972, ZMA Amph. 103.728, many specimens.

- Montpellier, river Hérault near St. Bauzille-de-Putois, 23-V-1972, ZMA Amph. 103.728, many specimens.

Dépt. Lot:

- River Célé, 500 m N.E. of Figeac, Aurillac, 18-VII-1972, ZMA Amph. 103.735, many specimens.

- Rivulet Masse, Cazals near Gourdon, VI-1971, ZMA Amph. 103.031, 3 specimens.

- Rivulet Ceou, l'Abbaye Nouvelle near Gourdon, VI-1971, ZMA Amph. 103.032, many specimens.

- Rivulet Tolerme near St. Céré, VI-1971, ZMA Amph. 103.033, 7 specimens. 